\title{
Do Political Economy Factors Influence Funding Allocations for Disaster Risk Reduction?
}

\author{
Shafiqul Islam ${ }^{1, *}$, Khondker Mohammad Zobair ${ }^{2}$, Cordia Chu ${ }^{3}$, James C. R. Smart ${ }^{1}$ and Md Samsul Alam ${ }^{4}$ \\ 1 School of Environment and Science, Griffith University, Nathan, QLD 4111, Australia; j.smart@griffith.edu.au \\ 2 Business School, Griffith University, Nathan, QLD 4111, Australia; k.zobair@griffith.edu.au \\ 3 Centre for Environment and Population Health, School of Medicine, Griffith University, \\ Nathan, QLD 4111, Australia; c.chu@griffith.edu.au \\ 4 Leicester Castle Business School, De Montfort University, Leicester LE1 9BH, UK; samsul.alam@dmu.ac.uk \\ * Correspondence: shafiqul.islam@griffithuni.edu.au
}

Citation: Islam, Shafiqul, Khondker Mohammad Zobair, Cordia Chu, James C. R. Smart, and Md Samsul Alam. 2021. Do Political Economy Factors Influence Funding Allocations for Disaster Risk Reduction?. Journal of Risk and Financial Management 14: 85. https://doi.org/10.3390/jrfm14020085

Academic Editor: Michael McAleer

Received: 4 January 2021

Accepted: 3 February 2021

Published: 20 February 2021

Publisher's Note: MDPI stays neutral with regard to jurisdictional claims in published maps and institutional affiliations.

Copyright: () 2021 by the authors. Licensee MDPI, Basel, Switzerland. This article is an open access article distributed under the terms and conditions of the Creative Commons Attribution (CC BY) license (https:// creativecommons.org/licenses/by/ $4.0 /)$.

\begin{abstract}
Considering the importance of political economy in implementing Disaster Risk Reduction (DRR), this research investigates the significance of political economy in the distribution of DRR funding in Bangladesh. The study analysed data from self-reported surveys from 133 members of the sub-district level disaster management committee and government officials working with DRR. Employing the Partial Least Squares Structural Equation Modeling (PLS-SEM) method, we find that political economy factors explain $68 \%$ of the variance in funding allocations. We also show that four categories of political economy factors-power and authority, interest and incentives, institutions, and values and ideas-are significantly influential over the distribution of DRR funding across subdistricts of Bangladesh. Our findings offer important policy implications to reduce the potential risks surrounding political economy influences in fund allocation and advance climate finance literature.
\end{abstract}

Keywords: Bangladesh; disaster risk reduction (DRR); fund distribution; PLS-SEM; political economy; climate finance

\section{Introduction}

Climate-related disasters are increasing globally. Many initiatives and efforts to mitigate the disaster risks are undertaken by disaster risk reduction (DRR) practitioners (UNISDR 2005, 2015). Previous research has shown that funding distributions for these efforts are determined not only by local needs, disaster risks, and climate vulnerability but also by political economy factors such as the influence of dominant stakeholders (Alam et al. 2011; Marks and Lebel 2016; Mogues 2015; Purdon 2015; Vorhies 2012). Influential bodies select the issues of concern and decide funding amount and location selection (Francken et al. 2012; Fritz et al. 2014) and high-ranking decision-makers influence the process by which some issues and locations receive priority access to funding whilst others do not (Garrett and Sobel 2003; Neumayer et al. 2014; Sovacool et al. 2016). This phenomenon exists throughout the world and has been specifically identified in Bangladesh (Alam et al. 2011; Sovacool 2018).

Bangladesh contributes little to global climate change, yet it is highly vulnerable to climate-related disasters (Chowdhury 2012; IPCC 2012). Although Bangladesh has many success stories in managing disaster risks, the country confronts several challenges surrounding DRR including lack of capacity among actors and institutions (Alam et al. 2011), lack of collaboration, and coordination (Sovacool 2018), lack of better governance (Bhuiyan 2015; Islam et al. 2020a), inappropriate distribution of scarce fund (Islam 2014; Mallick 2014), and misappropriation in fund distributions (Transparency International Bangladesh 2017). Previous researches also have shown that power relations, resource distribution, and interaction among key stakeholders, hinder DRR efforts in Bangladesh 
(Alam et al. 2011; Izumi and Shaw 2014; Sovacool 2018). Moreover, the distribution of DRR funds is influenced by electoral benefit-based distribution (Besley and Burgess 2002), the influence of the party in power (Francken et al. 2012), discrimination against a weaker section of the society (Jha 2015), and elite control over resource distribution (Watts 2000). The way DRR planners and practitioners act has implications on the potential risks of inefficient use of resources, increased loss and damage, increased inequality in project fund allocations (Rawlani and Sovacool 2011; Sovacool et al. 2016). These DRR challenges can be considered a political economy problem (DFID 2009b; Islam et al. 2020b; Mogues 2015; Purdon 2015) because they concern the distribution of resources and interactions among stakeholders.

Therefore, public fund distribution is often influenced by political economy factors such as power and authority, interests, and incentives, institutions, values, and ideas of key decision-makers (DFID 2009b; Mogues 2015). However, these factors are not measurable quantitatively; neither can be explored by asking questions directly to the stakeholders. Consequently, this study applies a partial least square structural equation model (SEM) approach to study the role of the political economy factors in the public spending distribution.

The main objective of this study is to investigate the potential relationship between the role of political economy factors, more specifically, the power and authority, interest and incentives, institutions, values and ideas of the influential decision-makers, and the decisions regarding DRR fund distributions in Bangladesh. We collect primary data from 133 members of the sub-district level disaster management committee and government officials working with DRR by using structured question. Our analysis shows that political economy factors explain $68 \%$ of the variance in funding allocations. We also show that four categories of political economy factors-power and authority, interest and incentives, institutions, and values and ideas-are significantly influential over the distribution of DRR funding across subdistricts of Bangladesh.

This study contributes to the existing literature and policy implication in four ways. First, this is one of the pioneer study that investigates the role of political economy factors in the distribution of DRR funding by considering Bangladesh as an interesting case study in the context of public fund distribution for climate-related disasters. Second, this study contributes to the wider literature (Adams and Neef 2019; Fumey and Egwaikhide 2018; Sovacool et al. 2018) that examine the nexus between political economy and public fund distribution by employing a novel PLS-SEM approach, which is a powerful and wellaccepted analytic tool (Chin 1998) to evaluate the measurement of latent factors and test the relationships between latent factors (Hair et al. 2014). Moreover, PLS-SEM works efficiently with small sample sizes and complex models (Hair et al. 2017) without demanding any distribution parameters (Corder and Foreman 2014) or assumptions (i.e., it is nonparametric) (Vilares et al. 2010). Thus, this study used the PLS-SEM method deemed appropriate to increase the explanatory power of regression that explains the influencing factors that underlie decisions regarding the DRR fund distributions. Third, by applying factor analysis to aggregated data from DRR stakeholders in Bangladesh, this study empirically tested the theory that political economy elements-power and authority, interest and incentives, institutions, and values and ideas can influence the decision regarding public fund distribution in DRR. Fourth, along with academic contributions to climate finance literature, this study has important policy implications-the policymakers and influencing authorities surrounding DRR fund distribution can have lessons to identify efficient and effective mechanisms for funding distribution.

The rest of the paper is organised as follows. A brief literature review is provided in Section 2 while Section 3 introduces the analytical methodology and data used in this study. Data analysis and results are presented in Section 4, the discussion is in Section 5, and the conclusion and implications presented in Section 6. 


\section{Review of the Literature: Hypotheses and Conceptual Model}

\subsection{Political Economy in DRR}

"It is not from the benevolence of the butcher, the brewer, or the baker, that we expect our dinner, but from their regard to their interest" (Smith [1776] 1937, p. 13). From Smith onwards, political economists sketched how the market system and the private interests move toward fulfilling the satisfaction of desires other than their own (Stiglitz 1998). Political economy analysis enquires how the power and authority of influencing stakeholders, their interests and incentives, values, and ideas-religious or political, interact with formal and informal institutions to influence the decision regarding the distribution of scarce resources (DFID 2009b; Mogues 2015; Serrat 2017). This scenario is also found in the DRR-related funding distribution. An extensive literature has been explored with the main factors influencing observed patterns of DRR related fund distribution to different regions and stakeholder groups. Among early studies, Cox and McCubbins (1986) identified the politicised distribution of relief mainly to supporters for electoral benefits. Influential decision-makers seek to increase their votes by pleasing their supporters instead of distributing funds based on disaster vulnerability.

Normatively, disaster-prone areas and communities with a high poverty rate of poverty, high unemployment rate, and low levels of development need to receive more funds from the central government and international organisations (Islam et al. 2020a). The regions or communities affected by disaster risks need to receive more funds. Based on risk assessment theory, storm surges are simulated in numerical models, and the flooding area and depths are calculated using remote sensing data and GIS (Liu et al. 2018). Disaster risk also can be viewed from people's perception on the premise of culture and experiences (Bempah and Øyhus 2017). Considering these, international documents such as the Hyogo framework-2005, and the Sendai framework-2015, together with local Bangladeshi legislation such as disaster management acts, five-year plans, and other relevant rules and policies also support normative strategies for allocation of DRR funds.

However, the distribution of DRR funds is influenced by political economy factors in several ways. Firstly, power struggles have been shown to prevail in claiming ownership over resources (Alam et al. 2011; Watts 2000). Besley and Burgess (2002) found that the higher the electoral accountability of a government, the higher the allocation of food and relief related public expenditure in India. Secondly, voters (supporters) are favoured by the party in power when the disaster fund is distributed (Healy and Malhotra 2009). Francken et al. (2012) also found that governments' relief distribution aligns with political influences in Madagascar. Thirdly, disparities in socio-economic power often led to the weaker section of society being deprived of funding through the influences of dominant decision-makers (Jha 2015).

Therefore, it is evident that among many challenges in DRR, issues of governance, institutional arrangement, and proper fund distribution are clearly central (Birkman et al. 2009; Kelman et al. 2015; Mercer 2010; Mitchell et al. 2010; Schipper 2009; Thomalla et al. 2009; Venton and Trobe 2008). The need for political economy analysis around DRR is voiced by a growing body of literature that recognises its importance in identifying an effective way forward for disaster initiatives. (Alam et al. 2011; Collinson 2003; DFID 2009b; Fankhauser et al. 2015; Islam et al. 2020c; Keefer 2009; Purdon 2015; Sovacool and Linnér 2015). The researchers suggest that a political economy analysis will identify differences in governance practices (Bhuiyan 2015), clarify power struggles over the claim of limited resources (Alam et al. 2011), and demonstrate who influences choices and in what way (Kelman and Gaillard 2010). The political economy analysis explains some questions such as how people behave in dealing with disasters and how they are influenced by economic and political forces (Cannon et al. 2003; Hewitt 1995; Wisner et al. 2003). The DRR researchers discussed these issues, but identifying political economy factors in DRR fund distribution quantitatively is scarce. To identify the political economy nexus (DFID 2009b; Mogues 2015; Purdon 2015), this study focuses on (a) power and authority, (b) interests and incentives of influencing stakeholders, (c) the role of formal, and informal institutions, 
and (d) ideological, and religious values that influence decisions regarding allocation of scarce resources within DRR in Bangladesh.

\subsection{DRR Related Fund Allocation Practices in Bangladesh}

This study selected Bangladesh as a case study due to its extreme vulnerability to disaster, and climate-related impacts and the resource scarcity it faces (Mirza 2002). In Bangladesh, there are many initiatives, efforts, projects, and programs surrounding DRR (Shaw et al. 2013). Under the DRR umbrella, the Department of Disaster Management (DDM) of the Ministry of Disaster Management and Relief is implementing the construction of flood shelters, cyclone shelters, a 40 days employment generation program, and a social safety net program, and other related initiatives (Hasan et al. 2013; Sabur 2012). The role of influencing stakeholders sometimes leads to inefficient use of resources and overlapping of projects in the same area/issues (Alam et al. 2011; Islam et al. 2019; Rawlani and Sovacool 2011). We collected the official documents relating to the construction of 273 rural flood shelters implemented by DDM as a case study. By inspecting these documents and visiting some shelters, we scrutinised the projects' name and title, compared the locations, and issues concerning the projects in different districts.

Based on poverty, vulnerability, loss, and damage of the disaster affected people and locations DRR-funds need to be distributed (Sawada and Takasaki 2017). DRR-fund allocations are made, for instance, for curving poverty in China (Cao et al. 2016), for reducing disaster risks in Wenchuan (Xie et al. 2018), for the locations and communities most in need (Bailey and Harvey 2015), in order house building for the poor (Freeman 2004), and the recovery of flood-vulnerable populations (Muñoz and Tate 2016). The Hyogo framework 2005 and the Sendai framework 2015 also proposes that flood-prone, cycloneprone, or other disaster-prone areas and locations with high poverty rates need to receive more funds (UNISDR 2005).

The Bangladesh Government also has asserted in national-level policies that specify how DRR-related funds should be allocated, considering whether a region is disasterprone or not (DDM 2016, pp. 6-7). The policies also suggest that priority should be given considering the area size, population size, and the poverty rate of an area (Ministry of Disaster Management and Relief 2010a, 2012, Article 27). The Disaster Management Act 2012 mentioned the requirement to construct shelters (Ministry of Disaster Management and Relief 2012, article 21). In connection to this Act, the Disaster Management Policy 2015 has emphasised the necessity for flood shelters in low lying lands, river erosion-prone, and flood-prone areas (Ministry of Disaster Management and Relief 2015, policy no. 3.2). The key purpose stipulated in the project proposal of the "construction of flood shelter project" is as follows: "contributing to the national economy through reducing disaster risk and loss and damage in flood-prone and river erosion-prone areas of Bangladesh." Specific goals are "giving shelter to flood-affected people, securing animals and other resources, using shelters as educational institute when there is no flood" (Ministry of Disaster Management and Relief 2008, p. 1).

However, Figure 1, drawn based on official fund distribution-information, demonstrates that the districts with the highest populations, highest poverty rate, largest size, and the district most flood-affected have not been allocated the highest number of shelters from 2008 to 2017. Several districts, such as Kurigram, was allocated a reasonable portion of total funds, whereas others, such as Sunamganj (one of the most affected districts), was not allocated a reasonable fund. Similarly, the Kishoreganj district received the highest number of shelters, although this decision deviated from all the mandatory criteria mentioned above. 


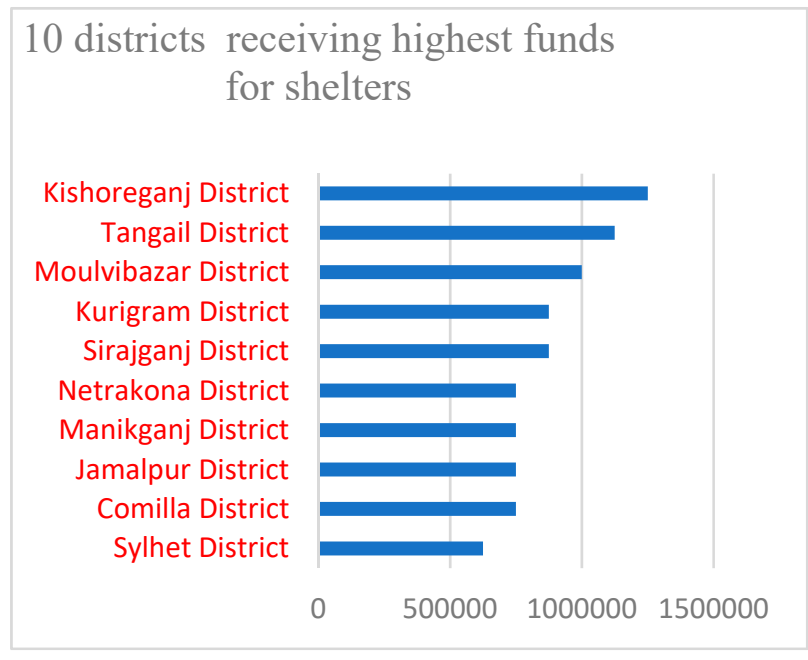

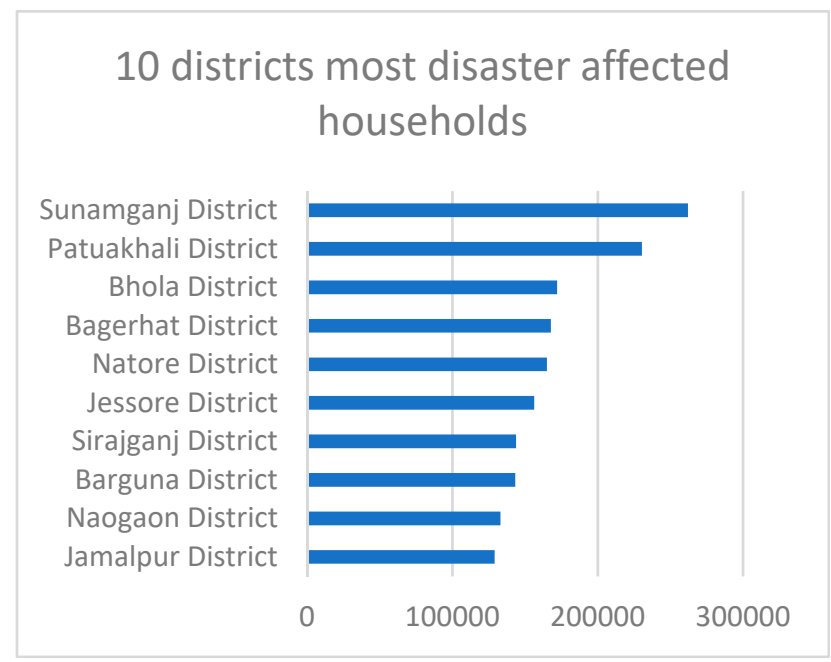
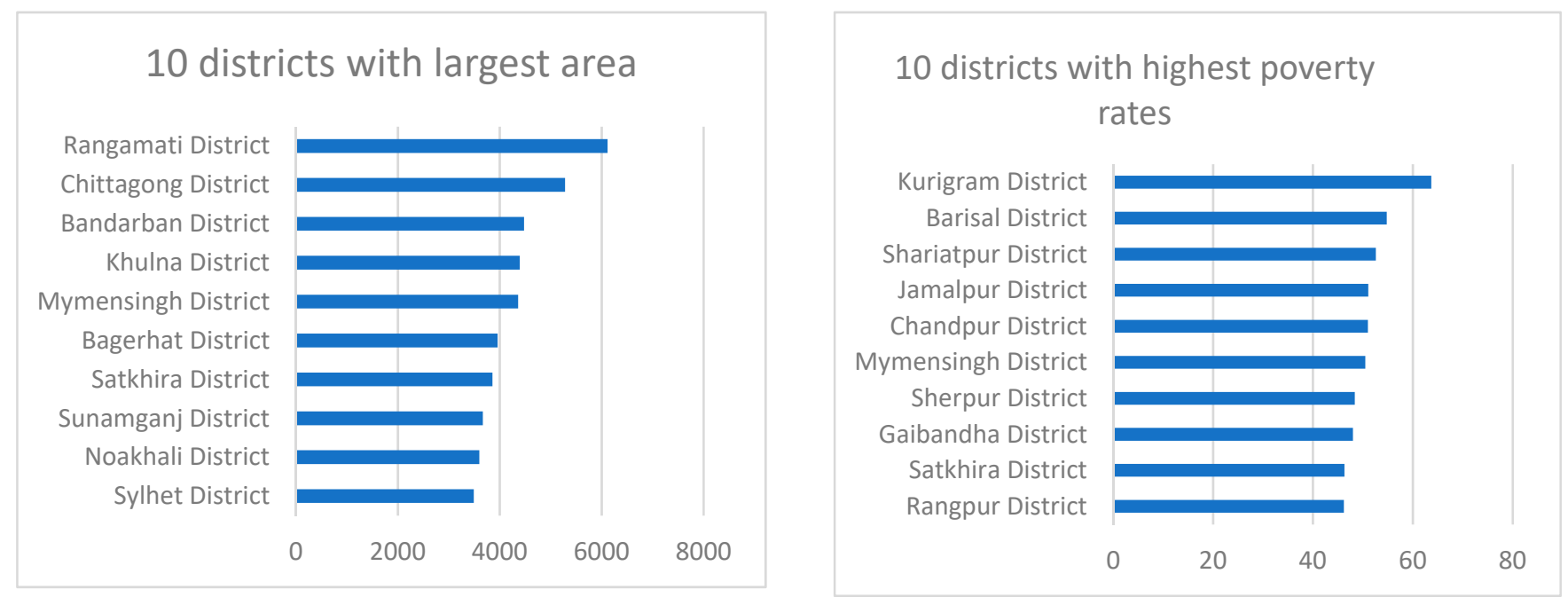

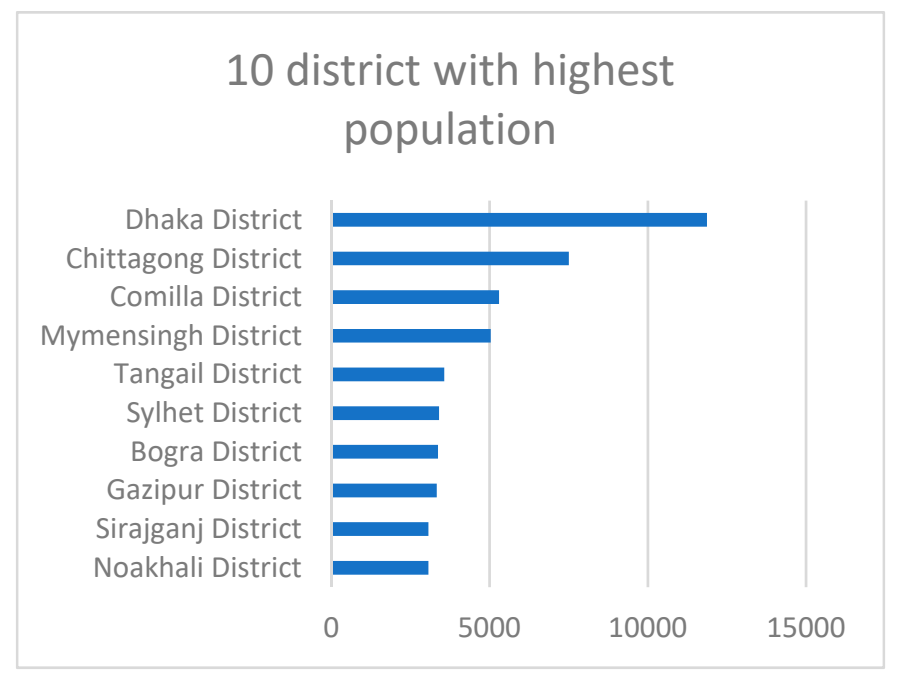

Figure 1. The districts receiving the most flood shelters, the most flood-affected districts, the districts with the largest area, and the districts with the highest poverty rates (drawn by the author based on the official documents of Department of Disaster Management (DDM) and Bangladesh disaster-related statistics 2015: Climate Change and Natural Disaster Perspectives by Bangladesh Bureau of Statistics). 
In addition, the distribution of flood shelters into the terms of location and beneficiaries, and the engagement scenario in Figure 1 shows that despite the funds were intended to be allocated to flood-prone areas, a few improper allocations were found. There has been an overlapping of projects in the same area and for the same issues. The reasons for these inappropriate allocations were identified by the analysis of the survey of this study.

\subsection{Conceptual Model}

The literature suggests that research can vary in accordance with researchers' perspective of the problem (Vishwanath and Scamurra 2007). No theoretical or conceptual framework so far appears to exist concerning the role of political economy factors in decisions regarding the DRR fund distributions. This represents a considerable knowledge gap. Consequently, drawing on the literature and background knowledge of DRR funding distribution in Bangladesh described above, the following hypotheses ( $\mathrm{H} 1, \mathrm{H} 2, \mathrm{H} 3, \mathrm{H} 4, \mathrm{H} 5$, and H5) are proposed to develop a conceptual model (Figure 2) for this study.

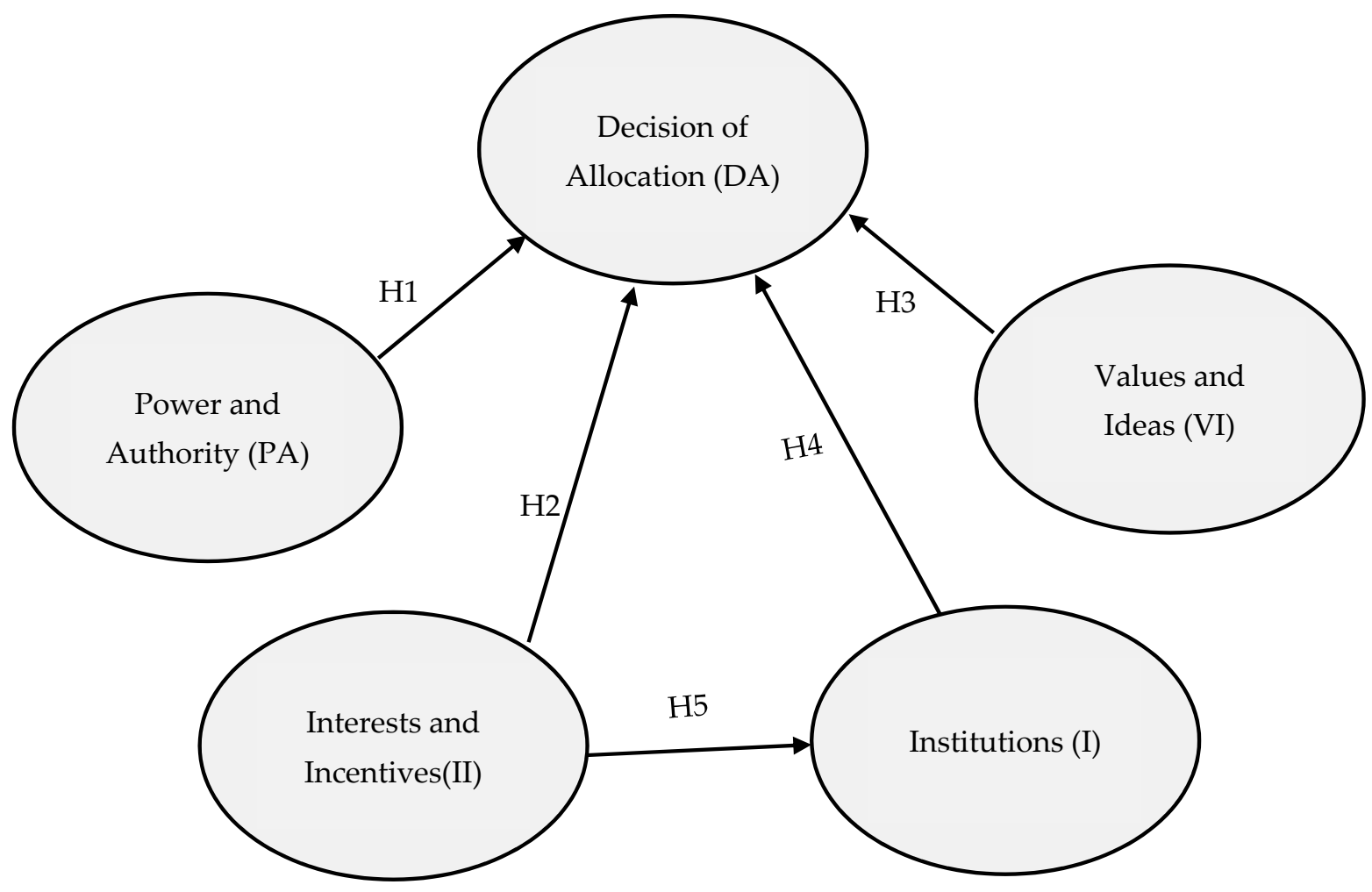

Figure 2. Conceptual Model: The proposed relationship between political economy factors-Power and Authority, Interest and Incentives, Institutions, Values and Ideas, and a Decision regarding allocation of Disaster Risk Reduction (DRR) funding.

\subsubsection{Power and Authority}

Hypothesis 1. Power and Authority influence the decision on the allocation of DRR funding.

The hypothesis is drawn from the following literatures. Patterns of power, rule, and authority influence in the government mechanism (Dahl 2005), where power, authority, conflict, and conflict resolution which are all bound up with these process (Caporaso and Lavine 2005). In addition, to what extent is a power assigned to some influential stakeholders and how interest groups inside and outside the government play their role matters in distribution (DFID 2009b). Literature argued that the power and authority of influencing stakeholders determine DRR fund allocation process, such as the establishment of cyclone shelters neither by right-based nor a demand-based planning approach (Mallick 2014), uneven distribution by the central government with monopolising power (Marks 
and Lebel 2016), and electoral politics, power struggles and competing priorities direct resources allocation (Besley and Burgess 2002; Healy and Malhotra 2009).

2.3.2. Interest and Incentives

Hypothesis 2. Interest and Incentives influence the decision on the allocation of DRR funding.

The hypothesis is derived from the following discussion. Interests and incentives influence the decisions of influencing bodies in many ways, including the influence of economic and political relationships on individual and group decisions (DFID 2009a; Fritz et al. 2014), and domination of self-preservation in fund distributions (Georgiou 1973). In addition, a given priority for some people than others may happen such as distributing more resources to voters or supporters for electoral benefits (Besley and Burgess 2002; Clark and Wilson 1961; Sovacool and Linnér 2015). Moreover, incentives work when the resources are scarce (Wade 1986) and encourage dominating stakeholders to cooperate in reinforcing incentives (Seabright 1993). Thus, some dominating stakeholders utilise the governance mechanisms of the allocation process to grab the benefits in pursuit of their interests (Sovacool 2018). Similarly, the interest and incentives of institutions decide the disaster risk reduction policy and practices (Vorhies 2012). Sovacool and Linnér (2015) also demonstrated how the influential interest groups include or exclude the community from the benefits of climate change adaptation initiatives.

\subsubsection{Institutions}

Hypothesis 3. Formal and Informal Institutions influence decisions on allocation of DRR funding.

The hypothesis is drawn from the following literatures. Institutions are the rules, norms, and conventions governing human interaction (Dellmuth et al. 2017), and these may be formal rules and laws, or informal social and cultural norms (Helmke and Levitsky 2004). In a setting such as Bangladesh where formal institutions are fragile, informal norms often direct how, and why issues really happen (DFID 2009b; Fritz et al. 2014). Institutions such as rules, regulations norms, expectations, and committees can reinforce each other in the mobilisation, and operationalisation of decision-making power (Cleaver 1998). Institutional structures such as laws and regulations and organograms influence DRR distribution (Kenny 2012; Næss et al. 2005; Rose and Kustra 2013).

\subsubsection{Values and Ideas}

Hypothesis 4. Values and Ideas of the actor's influence decision on allocation of DRR funding.

The hypothesis is derived from the following discussion. Values and ideas based on political ideologies, religion, or cultural beliefs, may influence political and economic behaviour (Campbell 1998; DFID 2009b). Ideas are mental programs such as existing setup and knowledge, or public sentiments, and so on (Campbell 1998). Values have an intrinsic and extrinsic dimension that influences perception and attitude which in turn influences behaviour (Homer and Kahle 1988; Lee et al. 2007). A list of values developed and tested by Kahle (1983) consists of nine values included a sense of belonging, selfrespect, and self-fulfillment that can be used to elucidate an individual's decision. Values and ideas shape the actions and distribution outcomes in DRR related distribution and divert from normative goals (Adam and Dercon 2009; Depoorter 2006; Francken et al. 2012; Sokefeld 2011).

2.3.5. The Relation between Endogenous Variables

Hypothesis 5. Interests and incentives of the actors influence institutions. 
The hypothesis is based on the following discussion. A circular or cyclical relationship among political economy components is frequently encountered. In some situations, power and authority, interests and incentives, institutions, and values and ideas can reinforce each other (Mogues 2015; Stiglitz 1998). In particular, power and authority, and interests and incentives of powerful decision-makers, can lead to the use, and misuse, of formal/informal institutions, values, and ideas, and vice versa (DFID 2009b; Purdon 2015). Powerful decision-makers are influenced by political beliefs, and religious ideologies (Lee et al. 2007), and incentives of the influential actors determine institutions (Cleaver 1998).

\subsubsection{Decisions about Distribution of the Public Fund}

Normatively, the funding from DRR related projects and programs should be distributed based on the population size, area, poverty rate, and disaster risk of a district and subdistrict as per existing policies, rules, and acts (Government of Bangladesh 2017). However, the location and beneficiary and engagement scenario suggest that though the funds are intended to be allocated to areas that are vulnerable to disaster and climate change, sometimes deviations occur because of political economy factors (Sovacool 2018; Tashmin 2016).

\section{Methodology}

This study has used a quantitative approach to empirically test the conceptual model of the interrelations between political economy elements (latent variables)-power and authority, interest and incentives, institutions, values and ideas, and decisions regarding the allocation of DRR fund.

\subsection{Research Instruments: Latent Variables and Indicators}

The latent variables, namely-power and authority; interest and incentives; institutions, values and ideas are extracted from the extant literature (DFID 2009b; Mogues 2015; Purdon 2015; Sovacool and Linnér 2015). The indicators (area size, population size, floodprone area) for the latent variable "decision of allocation" are also extracted from relevant policies of Bangladesh and relevant studies (Karim and Noy 2020). These variables are further confirmed by consultation with relevant experts. Questionnaire indicators were then selected and grouped under these five latent variables. Indicators under each latent variable are not from any questionnaire used by previous studies. Rather these indicators are screened, themed, prepared from the literature on DRR and in-depth interviews with key experts in the DRR field. We have consulted experts on DRR (both researchers and practitioners) to understand how latent variables influence DRR related public fund distributions.

Comprehending and estimating the extent of political economy elements by asking direct questions is complex and sensitive. PLS-SEM was used to analyse the data set (Muthupoltotage and Gardner 2018). It primarily consists of latent constructs that cannot be measured directly, requiring a set of indicators that serve as proxies (Hair et al. 2017). A PLS-SEM path model incorporates two sets of linear equations-a measurement model specifying a construct and its corresponding indicators and a structural model determining the relationship between exogenous and endogenous constructs (Henseler et al. 2017). Therefore, we used indirect assessment of attitudinal statements with Likert scale-agreement/disagreement for measuring associations between latent constructs and the decision of allocation via PLS-SEM. 


\subsection{Questionnaire Design}

Data collection commenced with the preparation of a questionnaire for the survey. The questionnaire was designed to investigate perceptions of the four latent variables(construct)power and authority, interest and incentives, institutions, and values and ideas to elicit responses from DRR practitioners in Bangladesh. The survey comprised a set of attitudinal statements ("indicators") to which respondents reply on a five-point Likert scale of agreement/disagreement (Petrides and Furnham 2000). Attitudinal statements were chosen to provide suitable potential coverage of the four latent variables that are hypothesised to influence DRR allocation decision. There are three to six attitudinal statements in the survey associated with each of the underlying PE factors.

We developed appropriate statements so that the respondents can understand the questions and then used same categories and terms so that stakeholders can understand the meaning similarly (Roine et al. 2016). For this, the study went through several months of preparation, with survey tests with sample questionnaires and in-depth discussions with a couple of probable respondents of DRR field. Before launching the full survey, a pilot survey was conducted with 15 relevant participants in Bangladesh, leading to further adjustments. Finally, after a few necessary modifications, the questionnaire was used in this study.

\subsection{Population and Sample}

All respondents have all the following three characteristics on which they are selected: (a) they are the key government official of a subdistrict; (b) they are the significant member of the subdistrict level disaster management committee; and (c) they are involved with DRR fund allocation process and have a minimum of five years' experience. The stratified random sampling (Ye et al. 2013) was used to select respondents. Bangladesh has six divisions, 64 districts, and 490 subdistricts. Starting with all six divisions of Bangladesh, we selected those districts of each division which are disaster-prone. In total, we selected 17 flood-prone districts (Bangladesh Bureau of Statistics 2015). Finally, the study covered each of the flood-prone subdistricts of these 17 flood-prone districts (Figure 3), thus covering 150 flood-prone subdistricts in total. Overall, we selected these districts and subdistricts purposefully, as the focus of this study is disaster-prone areas.

There is no consensus in existing studies that used PLS-SEM on the acceptable sample sizes. Saunders et al. (2009) opined that when size of the population is unknown, the representing minimum sample size is acceptable. Collecting questionnaire data in DRR funding related research is challenging, and the characteristics we have fixed for this study has limited the number of respondents. If the data source is reliable, a small sample size, such as 50 is considered sufficient for PLS-SEM (Hair et al. 2016).

We have approached 150 officials working in subdistricts of Bangladesh. From them, 133 officials participated in this survey, and the remaining 17 have been denied. Data obtained from all the 133 respondents from 133 subdistricts was complete. The final research sample is $\mathrm{N}=133$. Ethical approval for this study was granted by the Griffith University Human Research Ethics Committee (2017/446). We did not provide no financial incentives for participating in the survey. 


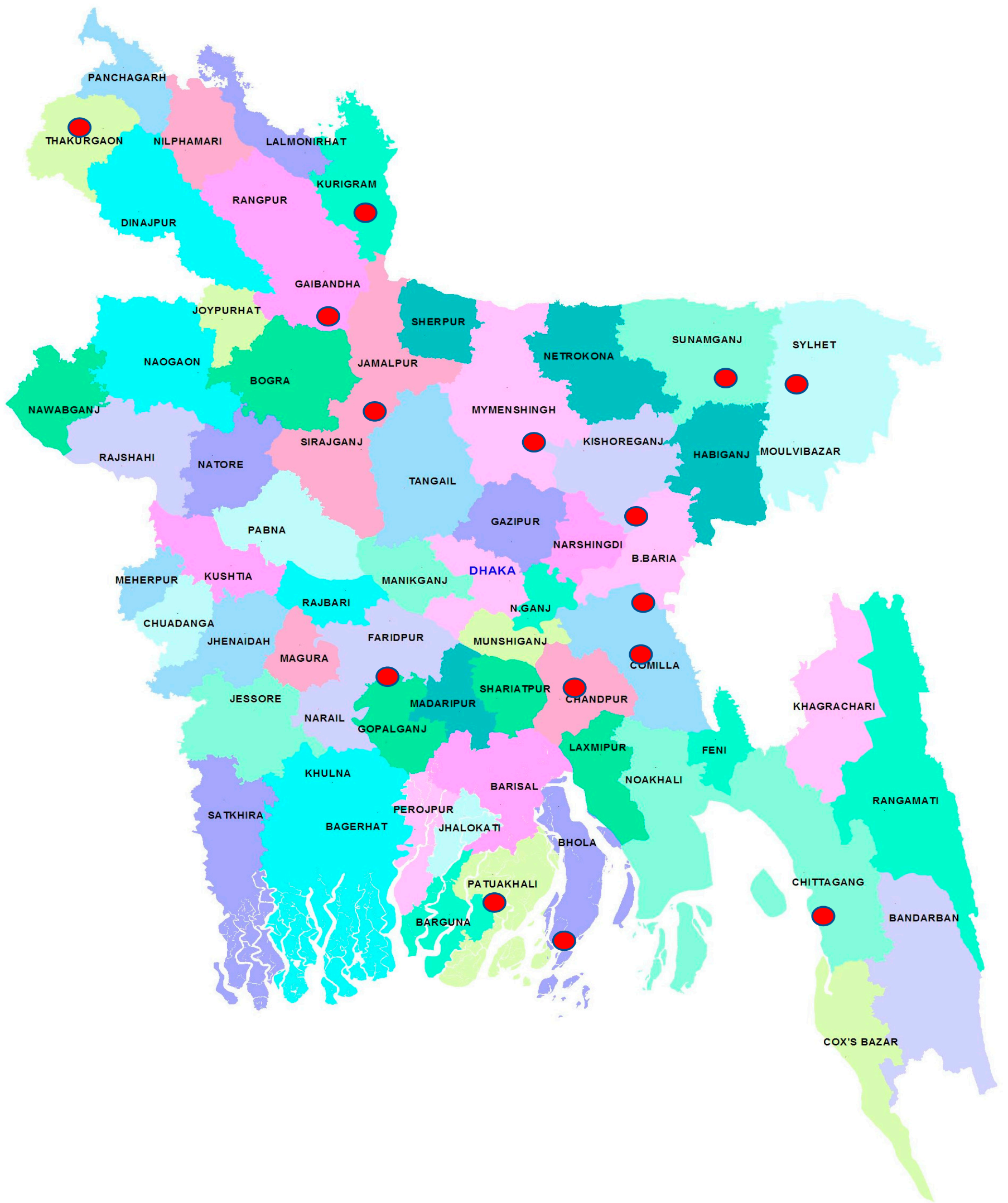

Figure 3. The data was collected from the red- marked districts, the areas affected by different types of climate-related disaster in Bangladesh (Ministry of Environment and Forest 2008). 


\subsection{Modelling and Analytic Approach}

The study followed a two-step analytic approach. The first step entails the measurement model, and the second step is the structural model (Anderson and Gerbing 1988). First, the measurement model specifies how latent constructs are measured using directional arrows pointing from indicators to the corresponding constructs (Hair et al.

2017). The reflective measurement model examines indicator reliability, internal consistency reliability, convergent validly, and discriminant validly for measurement assessment (Zobair et al. 2019).

Second, the study used the structural model to identify the hypothesised relationships between the latent variables and observed outcomes (decision of allocation). The structural model describes the latent constructs' relationships and examines their significance assessment (Roldán and Sánchez-Franco 2012). The structural model and hypothesised relationships between constructs can be tested using a standardised path coefficient $(\beta)$ and $\mathrm{t}$-statistics (Hair et al. 2017). The PLS algorithm tool was used for testing scale reliability in the measurement model, and a bootstrapping algorithm technique was used for hypothesis and structural model testing (Zobair et al. 2019). We use a bootstrapping procedure to examine statistical significance, including that of the structural model and the hypothesised relationships between endogenous and exogenous constructs (Zobair et al. 2019). Our proposed model can also test for endogenous relationships among the different latent variables. The purpose of using results regarding the strengths of these relationships (assessed via the estimated path coefficients) to test the research hypotheses that posit (i) that the different latent variables all significantly and separately influence allocation decisions and that interest and incentives of central actors influence institutions.

To ensure the validity of all measures, each of the indicators for latent variables within the proposed research model was developed from various prior studies (Hoque and Sorwar 2017). The measurement model was evaluated by testing composite reliability, convergent validity and discriminant validity (Hair et al. 2016). The criterion of Fornell and Larcker (1981) stated that the convergent validity of the measurement model can be assessed by the average variance extracted (AVE) and composite reliability (CR). AVE measures the variance covered by constructs versus measurement error; values above 0.7 are good, whereas, the level of 0.5 is acceptable. CR is a less biased estimate of reliability than Cronbach's Alpha. The acceptable value of CR is 0.7 and above. Discriminant validity can be analysed via the Fornell-Larcker criterion in which the square root of the AVE for each latent variable should be higher than the correlation values between any two variables in the model (Henseler et al. 2009).

\section{Data Analysis and Results}

This study applied survey-based research for empirical validation by employing a Partial Least Squares Structural Equation Modeling (PLS-SEM) approach that validates the research model and tests the research hypotheses (Marzagão and Carvalho 2016). SmartPLS version 3.2.7 was used to determine the measures' reliability and validity (Hoyle 2012).

\subsection{Measurement Model}

The measurement model was evaluated by testing composite reliability, convergent validity, and discriminant validity (Hair et al. 2017). Figure 4 shows that all except four of the standardised outer loadings for each of the indicators were higher than the threshold value of 0.70 (Hair et al. 2017), which suggests an adequate level of indicator reliability. Institutions (I) indicator, I2, I3 I4, and I6, had the standardised loadings of $0.671,0.632$, 0.651 , and 0.654 respectively; these were considered close to the cut-off value of 0.70 . Roldán and Sánchez-Franco (2012) noted that weaker indicators be retained if they make a meaningful contribution to content validity, but indicators with very low loadings of $\leq 0.40$ should be removed. Henseler et al. (2009) suggested that the correlation between a latent variable and its indicators' outer loadings should be $>0.70$ and any variables possessing indicators with values of less than 0.4 should be eliminated to substantially increase CR. 


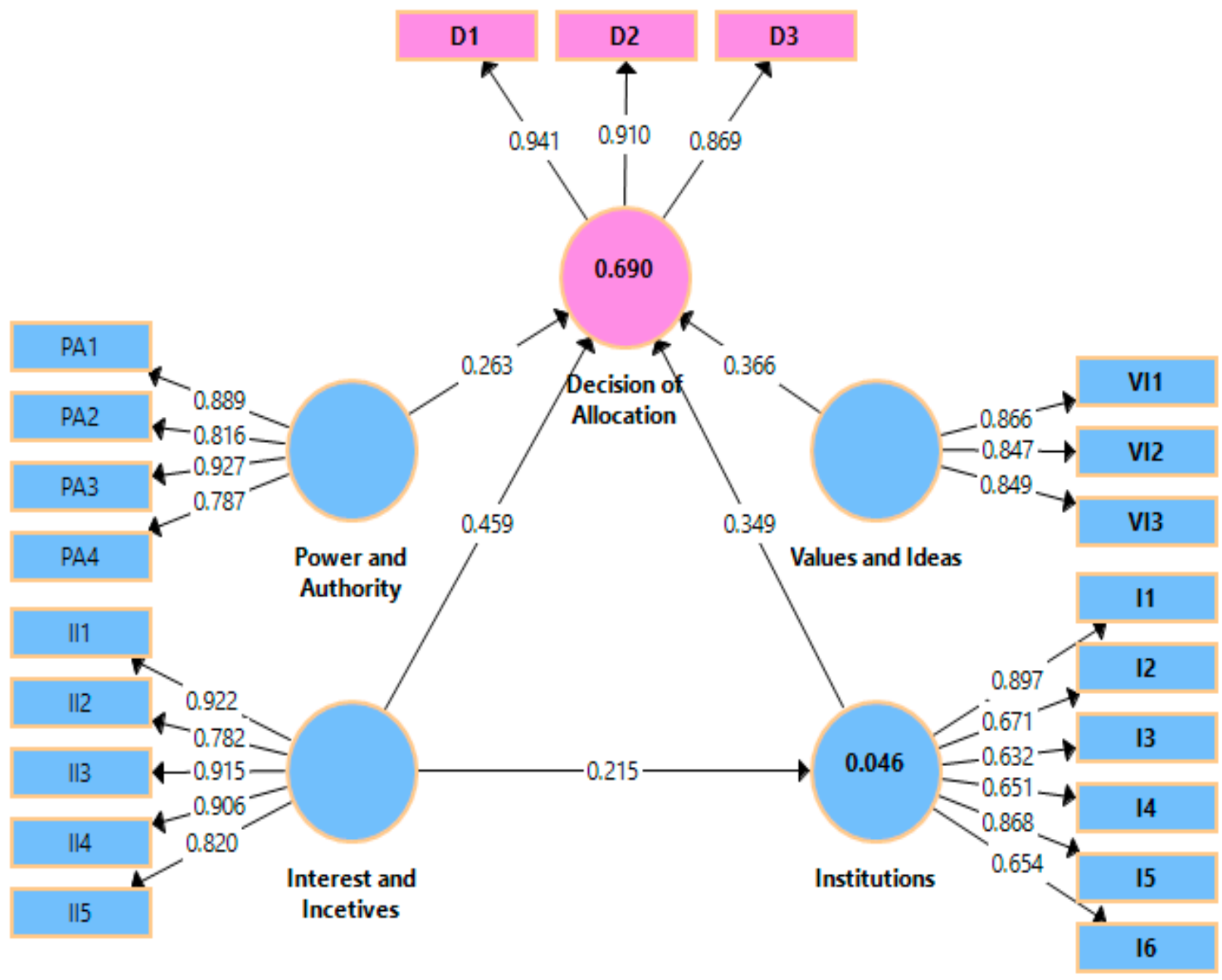

Figure 4. Final model: Partial Least Squares (PLS) structural model for Decision of Allocations.

Table 1 shows that the average variance extracted (AVE) values of each of the latent variables exceeded the threshold value of $>0.5$, indicating their significant convergent validity. The AVE values of the latent variable decision of allocation (DA) (0.823), power and authority (PA) (0.734), interest and incentives (II) (0.758), institutions (I) (0.543), and values and ideas (VI) (0.729) were higher than the threshold value of 0.50 , confirming that these latent variables demonstrated a high level of convergent validity (Hair et al. 2017). The AVE values in Table 1 shows that each of the latent variables explains the variance of more than half of their corresponding indicators, confirming their acceptable convergent validity (Hair et al. 2011). In testing the reliability assessment, Table 1 shows that both Cronbach's alpha and CR exceeded their threshold values of $>0.70$ (Hair et al. 2017) confirming that the measurement model is statistically significant. This provides strong evidence of internal consistency reliability. 
Table 1. Convergent Validity and Reliability Statistics of the Sample.

\begin{tabular}{|c|c|c|c|c|c|c|c|}
\hline $\begin{array}{c}\text { Latent } \\
\text { Variables }\end{array}$ & Indicators & $\begin{array}{l}\text { Standard } \\
\text { Loadings }\end{array}$ & $\begin{array}{l}\text { Average Variance } \\
\text { Extracted (AVE) }\end{array}$ & $\begin{array}{c}\text { Composite } \\
\text { Reliability (CR) }\end{array}$ & $\begin{array}{c}\text { Cronbach's } \\
\text { Alphas }\end{array}$ & $R^{2}$ & Adjusted $R^{2}$ \\
\hline \multirow[t]{2}{*}{$\begin{array}{l}\text { Decision of } \\
\text { Allocations } \\
\text { (DA) }\end{array}$} & DA1 & 0.941 & 0.823 & 0.933 & 0.892 & 0.690 & 0.680 \\
\hline & $\begin{array}{l}\text { DA2 } \\
\text { DA3 }\end{array}$ & $\begin{array}{l}0.910 \\
0.869\end{array}$ & & & & & \\
\hline \multirow{2}{*}{$\begin{array}{l}\text { Institutions } \\
\text { (I) }\end{array}$} & I1 & 0.897 & 0.543 & 0.875 & 0.857 & 0.046 & 0.039 \\
\hline & $\begin{array}{l}\text { I2 } \\
\text { I3 } \\
\text { I4 } \\
\text { I5 } \\
\text { I6 }\end{array}$ & $\begin{array}{l}0.671 \\
0.632 \\
0.651 \\
0.868 \\
0.654\end{array}$ & & & & & \\
\hline \multirow[t]{2}{*}{$\begin{array}{l}\text { Power and } \\
\text { Authority } \\
\text { (PA) }\end{array}$} & PA1 & 0.889 & 0.734 & 0.916 & 0.882 & & \\
\hline & $\begin{array}{l}\text { PA2 } \\
\text { PA3 } \\
\text { PA4 }\end{array}$ & $\begin{array}{l}0.816 \\
0.927 \\
0.787\end{array}$ & & & & & \\
\hline \multirow[t]{2}{*}{$\begin{array}{l}\text { Interest and } \\
\text { Incentives (II) }\end{array}$} & II1 & 0.922 & 0.758 & 0.940 & 0.922 & & \\
\hline & $\begin{array}{l}\text { II2 } \\
\text { II3 } \\
\text { II4 } \\
\text { II5 }\end{array}$ & $\begin{array}{l}0.782 \\
0.915 \\
0.906 \\
0.820\end{array}$ & & & & & \\
\hline \multirow{3}{*}{$\begin{array}{l}\text { Values and } \\
\text { Ideas (VI) }\end{array}$} & VI1 & 0.866 & 0.729 & 0.890 & 0.817 & & \\
\hline & VI2 & 0.847 & & & & & \\
\hline & VI3 & 0.849 & & & & & \\
\hline
\end{tabular}

The bold text results (in Table 2) confirm that the square root of the AVE for each latent variable is higher than that variable's correlation with any of the other latent variables, indicating an acceptable level of discriminant validity for the PLS structural model (Hair et al. 2017).

Table 2. Discriminant Validity among Latent Variables in the measurement model.

\begin{tabular}{cccccc}
\hline & DA & I & II & PA & VI \\
\hline DA & $\mathbf{0 . 9 0 7}$ & & & & \\
I & 0.511 & $\mathbf{0 . 7 3 7}$ & & & \\
II & 0.565 & 0.215 & $\mathbf{0 . 8 7 1}$ & & \\
PA & 0.354 & 0.115 & 0.061 & $\mathbf{0 . 8 5 7}$ & \\
VI & 0.435 & 0.094 & 0.043 & 0.064 & $\mathbf{0 . 8 5 4}$ \\
\hline
\end{tabular}

Note. The square root of AVE in bold.

\subsection{Structural Model}

The structural model was developed to describe the relationships among all the latent variables and to examine their meaningfulness and significance in the research model (Roldán and Sánchez-Franco 2012). The structural model and hypotheses were tested by employing a bootstrapping technique (Hair et al. 2017). This technique estimates standard deviations, $t$-values and significance level ( $p$-values) and confidence intervals for standardised path coefficients for each hypothesised relationship in the structural equation model (Garson 2016). The path coefficient is a crucial, standardised regression coefficient that can be assessed for measuring significance levels in a structural model (Henseler et al. 2017). Table 3 shows the standardised path coefficients ( $\beta$ ), $t$-statistics, and $p$-values for each hypothesised relationship between latent variables in the structural model. 
Table 3. Structural Estimation of $t$-values and $p$ values for the Structural Model.

\begin{tabular}{cccccc}
\hline Hypothesis & $\begin{array}{c}\text { Path Coefficient } \\
(\boldsymbol{\beta})\end{array}$ & $\begin{array}{c}\text { Standard } \\
\text { Error }\end{array}$ & $\boldsymbol{t}$-Value & $\boldsymbol{p}$-Value & Decision \\
\hline $\mathrm{PA} \rightarrow \mathrm{DA}(\mathrm{H} 1)$ & $0.263^{* * *}$ & 0.260 & 3.845 & 0.000 & Supported \\
$\mathrm{II} \rightarrow \mathrm{DA}(\mathrm{H} 2)$ & $0.459^{* * *}$ & 0.454 & 7.713 & 0.000 & Supported \\
$\mathrm{I} \rightarrow \mathrm{DA}(\mathrm{H} 3)$ & $0.349^{* * *}$ & 0.348 & 4.136 & 0.000 & Supported \\
$\mathrm{VI} \rightarrow \mathrm{DA}(\mathrm{H} 4)$ & $0.366^{* * *}$ & 0.360 & 4.353 & 0.000 & Supported \\
$\mathrm{II} \rightarrow \mathrm{I}(\mathrm{H} 5)$ & $0.215^{* *}$ & 0.243 & 2.126 & 0.034 & Supported \\
\hline Note. ${ }^{* *} p<0.05 ;{ }^{* * *} p<0.01$ (two-tailed) confidence intervals for significant testing.
\end{tabular}

The structural model in this study revealed that four out of the five hypotheses were supported by relationships at a $p<0.01$ significance level; whereas one hypothesis at a $p<0.05$ significance level (see Figure 4). The results (see Tables 2 and 3) confirms that the four proposed latent variables had significant effects on the decision regarding allocation. Our findings show that the relationships between power and authority (PA), and the decision of allocation ( $\mathrm{PA}=\beta=0.263, t=3.845, p<0.01)$; the interest and incentives (II), and decision of allocation (II $=\beta=0.459, t=7.713, p<0.01$ ); the institutions (I) and decision of allocation ( $\mathrm{I}=\beta=0.349, t=4,136 p<0.01)$; and the values and ideas (VI), and decision of allocation ( $\mathrm{VI}=\beta=0.366, t=4.353, p<0.01$ ) were statistically significant in the case of DRR fund distribution at subdistrict level of Bangladesh. Further, an $R^{2}$ value of 0.68 reflects that the structural model provides a higher predictive capability. An $R^{2} \approx 0.680$ value indicates that about 68 per cent of the variance (i.e., decision of the allocation) in the model was jointly explained by the power and authority, interest and incentives, institutions, and values and ideas. The literature suggests that $R^{2}$ values should generally be 0.67 (i.e., substantial), 0.33 (i.e., moderate), or 0.19 (i.e., weak) (Chin 1998; Henseler et al. 2009). Our results show more than a substantial $R^{2}$ value, which suggests the model has a high predictive capability.

Further, our findings reveal that interest and incentive have a strong effect on institutions. The results demonstrate that the relationships between interest and incentives and institutions $(\beta=0.215, t=2.126, p<0.05)$ were significant, confirming that $\mathrm{H} 5$ is supported.

\section{Discussion}

This study applied PLS-SEM to investigate the association between political economy factors and the decision to distribute DRR-related public funds in Bangladesh. The findings are as follows.

Our finding from the survey shows the power and authority of important decisionmakers influence the allocation of DRR funding in Bangladesh. Results of this survey show similarities to the prior literature (Caporaso and Lavine 2005; DFID 2009b; Hinkin and Schriesheim 1989; Mallick 2014; Neal and Neal 2011) who claimed that electoral politics, power struggles, and competing priorities of the key decision-makers with power and authority had a direct influence on resources allocation in different context. Local and central leaders who have more connections with power and authority have more impact on the decision of allocations.

The result that interest and incentives of the influential stakeholders influence the decision of allocations of DRR matches conclusions from other literature (DFID 2009b; Fritz et al. 2014; Mogues 2015; Sovacool et al. 2015). Political incentives lie behind DRR allocations (Keefer 2009), and actors such as individuals or groups with shared interests and incentives, decide the allocation (DFID 2009b).

Our findings from the survey also suggest that institutions (formal and informal) affect the decision of allocations directly and indirectly via interests and incentives. Existing literature also reached similar conclusions (Cleaver 1998; DFID 2009b; Fritz et al. 2014; Helmke and Levitsky 2004). Institutions in the form of rules, regulations, norms and 
expectations, customs, committees and contracts can play a vital role in the decision of powerful stakeholders regarding resource distribution (Cleaver 1998).

Our finding of an association between values and ideas, and the decision of allocations of DRR funding is also in accordance with existing literature (Alam et al. 2011; Campbell 1998; Homer and Kahle 1988). Values and ideas, including political ideologies, religion, and cultural beliefs have been shown to shape the decision of the key authorities (DFID 2009b).

Interestingly, no significant endogenous relationship was found between the political economy factors except for a relationship between "interests and incentives" and "institutions". Our findings reveal that interests and incentives have a significant effect on institutions. Existing studies, such as Mogues (2015) and Stiglitz (1998) also suggests that interests and incentives and institutions can reinforce each other.

Finally, the finding that political economy factors influence the decision of allocation of DRR funding is important. It means that stakeholders need to recognise these realities when seeking to achieve a funding paradigm based, as initially intended, on population size, land area, local needs, poverty level, and vulnerability to disaster. A recognition that political economy factors are at play is likely to be a necessary prerequisite for achieving effective allocation of resources by minimising overlapping inefficiencies.

Alternatively, one explanation for not distributing the DRR funds to the appropriate locations is the shortage of necessary funds, which causes the exclusion of many vulnerable areas that do not receive necessary DRR funds. That is why influential confronts with conflicting situations to receive more funds to their areas to satisfy their supporters. If the resources were not scarce, the political economy factors would not work much in Bangladesh. Another explanation is that although the political economy nexus of DRR can sometimes manipulate projects to the interests of dominant stakeholders, it does not mean that they fully undermine all the benefits of DRR. The result found in this study can be used for improving and learning to distribute to vulnerable location and affected community more efficiently. Practitioners need to become more cognizant of the distribution process.

The limitation of this study is that only the opinion form the survey of the key stakeholders of DRR in Bangladesh was considered. Further research should, ideally, extend our analysis to consider the opinions of a wider range of stakeholders, including external stakeholders. Data were collected only from disaster-affected subdistricts of Bangladesh as a sample. Although the resulting structural equation model did succeed in explaining a high proportion of the observed variance in DRR allocation decisions, future research may extend the analysis to consider other countries and contexts to enhance the generalizability of our results across DRR sector.

Further research is needed to enhance our understanding of the interrelationships between the political economy factors and the distribution of public funds surrounding DRR in other countries and contexts using these theories. An important area of future research concerns carefully evaluating the extent of the influence of political economy factors in DRR. Efforts should be made to obtain measures of exogenous and endogenous variables at different periods for DRR-related fund distribution. Furthermore, it will be useful to investigate differences of perception across various stakeholders surrounding DRR fund allocations.

\section{Conclusions and Implications}

The purpose of this study is to investigate the impact of political economy in the distribution of DRR funding in Bangladesh. The study collected primary data through structured questionnaire from 133 members of the sub-district level disaster management committee and government officials working with DRR. By employing a robust PLS-SEM approach, our results reveal that power and authority, interest and incentives, institutions, and values and ideas-are significantly influential over the distribution of DRR funding across subdistricts of Bangladesh

The findings strongly support the theory that the distribution of public DRR funds is significantly influenced by political economy factors surrounding the DRR sector in 
Bangladesh. Although the distribution of public funds should be based on population size, land area, local needs, and disaster risk as per the policy of Bangladesh in reality, the distribution processes are often influenced by the power and authority, interest and incentives, institutions and values and ideas of the influencing actors. Improper distribution of funds exacerbates severe inefficiency and ineffectiveness in using scarce resources and cause vulnerable people and locations to become even more deprived. The policymakers and influencing authorities surrounding DRR fund distribution to have a responsibility to consider how efficient and effective mechanisms for funding distribution can be made resistant and resilient to the adverse impacts of the sector's political economy. This study is expected to provide both instigation and insight for academic and practitioners to be guided towards successfully undertaking actions for efficient and effective funding distribution.

It is clear that DRR policymakers and practitioners need to swiftly modify their policies and processes to acknowledge the realities of the political economy surrounding funding distribution. Existing rules and procedures for proper fund distribution and proper selection of vulnerable locations and beneficiaries need to be strengthened and enforced with transparency to reduce the adverse influence of political economy factors; this is a necessity for building climate change and disaster-resilient sustainable development in Bangladesh.

Author Contributions: Conceptualization, S.I., and C.C.; methodology, S.I. and K.M.Z.; software S.I. and K.M.Z.; validation S.I.; K.M.Z. and M.S.A.; formal analysis, S.I. and K.M.Z.; writing-original draft preparation, S.I.; writing-review and editing, C.C., J.C.R.S., S.I., and M.S.A.; supervision, C.C. and J.C.R.S.; project administration, C.C., S.I., and J.C.R.S. All authors have read and agreed to the published version of the manuscript.

Funding: This research received no external funding.

Institutional Review Board Statement: The approved by the Griffith University Human Research Ethics Committee (2017/446).

Informed Consent Statement: Informed consent was obtained from all questionnaire survey respondents.

Data Availability Statement: Data can be available upon the request to the first author.

Acknowledgments: The authors are sincerely grateful to two anonymous reviewers for their constructive comments on the earlier version of the study which have led to a significant improvement in the quality of the paper.

Conflicts of Interest: The authors declare no conflict of interest.

\section{References}

Adam, Christopher, and Stefan Dercon. 2009. The political economy of development: An assessment. Oxford Review of Economic Policy 25: 173-89. [CrossRef]

Adams, Carl, and Andreas Neef. 2019. Patrons of disaster: The role of political patronage in flood response in the Solomon Islands. World Development Perspectives 15: 100128. [CrossRef]

Alam, Khurshid, Md Shamsuddoha, Thomas Tanner, Moshahida Sultana, Muhammad Jahedul Huq, and Sumaiya S. Kabir. 2011. The Political Economy of Climate Resilient Development Planning in Bangladesh. IDS Bulletin 42: 52-61. [CrossRef]

Anderson, James C., and David W. Gerbing. 1988. Structural equation modeling in practice: A review and recommended two-step approach. Psychological Bulletin 103: 411. [CrossRef]

Bailey, Sarah, and Paul Harvey. 2015. State of Evidence on Humanitarian Cash Transfers. Overseas Development Institute Background Note. Available online: https://www.alnap.org/system/files/content/resource/files/main/446-9591.pdf (accessed on 1 February 2021).

Bangladesh Bureau of Statistics. 2015. Bangladesh Disaster Related Statistics 2015: Climate Change and Natural Disaster Persepectives. Edited by Ministry of Planning Statistics and Information Division. Dhaka: Bangladesh Bereau of Statistics (BBS).

Bempah, Sherry Adomah, and Arne Olav Øyhus. 2017. The role of social perception in disaster risk reduction: Beliefs, perception, and attitudes regarding flood disasters in communities along the Volta River, Ghana. International Journal of Disaster Risk Reduction 23: 104-08. [CrossRef]

Besley, Timothy J., and Robin Burgess. 2002. The political economy of government responsiveness: Theory and evidence from India. Quarterly Journal of Economics 117: 1415-51. [CrossRef] 
Bhuiyan, Shahjahan. 2015. Adapting to Climate Change in Bangladesh Good Governance Barriers. South Asia Research 35: $349-67$. [CrossRef]

Birkman, Joern, Gerd Tetzlaff, and Karl-Otto Zentel. 2009. Addressing the challenge: Recommendations and quality criteria for linking disaster risk reduction and adaptation to climate change. In Addressing the Challenge: Recommendations and Quality Criteria for Linking Disaster Risk Reduction and Adaptation to Climate Change. Germany: German Committee for Disaster Risk Reduction, pp. 59-59.

Campbell, John L. 1998. Institutional analysis and the role of ideas in political economy. Theory and Society 27: 377-409. [CrossRef]

Cannon, Terry, John Twigg, and Jennifer Rowell. 2003. Social Vulnerability, Sustainable Livelihoods and Disasters. London: DFID.

Cao, Mengtian, Dingde Xu, Fangting Xie, Enlai Liu, and Shaoquan Liu. 2016. The influence factors analysis of households' poverty vulnerability in southwest ethnic areas of China based on the hierarchical linear model: A case study of Liangshan Yi autonomous prefecture. Applied Geography 66: 144-52. [CrossRef]

Caporaso, James A., and David P. Lavine. 2005. Theories of Political Economy. New York: Cambridge University Press.

Chin, Wynne W. 1998. The partial least squares approach to structural equation modeling. Modern Methods for Business research 295: 295-336.

Chowdhury, Faiz Ahm. 2012. Climate Change Finance and Governance: Bangladesh Perspectives. Dhaka: Institute of Governance Studies, BRAC University.

Clark, Peter B., and James Q. Wilson. 1961. Incentive systems: A theory of organizations. Administrative Science Quarterly 6: 129-66. [CrossRef]

Cleaver, Frances. 1998. Incentives and informal institutions: Gender and the management of water. Agriculture and Human Values 15: 347-60. [CrossRef]

Collinson, Sarah. 2003. Power, Livelihoods and Conflict: Case Studies in Political Economy Analysis for Humanitarian Action. London: Humanitarian Policy Group, Overseas Development Institute.

Corder, Gregory W., and Dale I. Foreman. 2014. Nonparametric Statistics: A Step-by-Step Approach. Hoboken: John Wiley \& Sons.

Cox, Gary W., and Mathew D. McCubbins. 1986. Electoral politics as a redistributive game. The Journal of Politics 48: 370-89. [CrossRef]

Dahl, Robert Alan. 2005. Who go.verns?: Democracy and Power in an American City. London: Yale University Press.

DDM. 2016. Construction of Flood Shelter. Retrieved on 23 January 2017. Available online: http://www.ddm.gov.bd/site/page/2b4 dff73-562d-4708-8212-85507d22d0a8/\%E0\%A6\%AC\%E0\%A6\%A8\%E0\%A7\%8D \%E0\%A6\%AF\%E0\%A6\%BE-\%E0\%A6\%86\% E0\%A6\%B6\%E0\%A7\%8D\%E0\%A6\%B0\%E0\%A7\%9F\%E0\%A6\%95\%E0\%A7\%87\%E0\%A6\%A8\%E0\%A7\%8D \%E0\%A6\%A6\%E0 $\% \mathrm{~A} 7 \% 8 \mathrm{D} \% \mathrm{E} 0 \% \mathrm{~A} 6 \% \mathrm{~B} 0$ (accessed on 1 February 2021).

Dellmuth, Lisa Maria, Dominik Schraff, and Michael F. Stoffel. 2017. Distributive politics, electoral institutions and European structural and investment funding: Evidence from Italy and France. JCMS: Journal of Common Market Studies 55: 275-93. [CrossRef]

Depoorter, Ben. 2006. Horinzontal political externalities: The supply and demand of disaster management. Duke Law Journal 56: 101-25.

DFID. 2009a. Political Economy Analysis How to Note. A DFID Practice Paper. London: Department for International Development.

DFID. 2009b. Defining Disaster Resilience: A DFID Approach Paper. London: DFID.

Fankhauser, Sam, Caterina Gennaioli, and Murray Collins. 2015. The political economy of passing climate change legislation: Evidence from a survey. Global Environmental Change 35: 52-61. [CrossRef]

Fornell, Claes, and David F. Larcker. 1981. Structural Equation Models with Unobservable Variables and Measurement Error: Algebra and Statistics. Los Angeles: SAGE Publications Sage CA.

Francken, Nathalie, Bart Minten, and Johan F. M. Swinnen. 2012. The Political Economy of Relief Aid Allocation: Evidence from Madagascar. World Development 40: 486-500. [CrossRef]

Freeman, Paul K. 2004. Allocation of post-disaster reconstruction financing to housing. Building Research E Information 32: 427-37.

Fritz, Verena, Brian Levy, and Rachel Ort. 2014. Problem-Driven Political Economy Analysis: The World Bank's Experience. Washington: World Bank.

Fumey, Abel, and Festus O. Egwaikhide. 2018. Political Economy of Intergovernmental Fiscal Transfers: The Rural-Urban Dynamics in Ghana. African Development Review 30: 33-44. [CrossRef]

Garrett, Thomas A., and Russell S. Sobel. 2003. The Political Economy of FEMA Disaster Payments. Economic Inquiry 41: 496-509. [CrossRef]

Garson, G. David. 2016. Partial Least Squares: Regression \& Structural Equation Models. Statistical Associates Blue Book Series; Asheboro: Statistical Associates Publishers.

Georgiou, Petro. 1973. The goal paradigm and notes towards a counter paradigm. Administrative Science Quarterly 18: 291-310. [CrossRef]

Government of Bangladesh. 2017. Policies, Acts and Laws. Available online: https://erd.gov.bd/site/page/f7908eb0--0ff9--408e-a7d0 --2dd6b2364078/Govt--Policies,-Acts-and-Laws (accessed on 25 January 2020).

Hair, Joe F., Christian M. Ringle, and Marko Sarstedt. 2011. PLS-SEM: Indeed a silver bullet. Journal of Marketing Theory and Practice 19: 139-52. [CrossRef]

Hair, Joe F., Jr., Marko Sarstedt, Lucas Hopkins, and Volker G. Kuppelwieser. 2014. Partial least squares structural equation modeling (PLS-SEM). European Business Review. Available online: https:/ /www.emerald.com/insight/content/doi/10.1108/EBR-10-2013$0128 /$ full $/ \mathrm{html}$ ? src $=$ recsys\&fullSc=1\&fullSc=1\&fullSc=1\&fullSc=1\&mbSc=1\&fullSc=1\&fullSc=1 (accessed on 23 February 2019). 
Hair, Joe F., Jr., G. Tomas M. Hult, Christian Ringle, and Marko Sarstedt. 2016. A Primer on Partial Least Squares Structural Equation Modeling (PLS-SEM). Thousand Oaks: Sage Publications.

Hair, Joe F., Jr., Carole L. Hollingsworth, Carole L. Hollingsworth, Adriane B. Randolph, Adriane B. Randolph, Alain Yee Loong Chong, and Alain Yee Loong Chong. 2017. An updated and expanded assessment of PLS-SEM in information systems research. Industrial Management \& Data Systems 117: 442-58.

Hasan, Z., S. Akhter, S. Ahmed, and A. Kabir. 2013. Challenges of Integrating Disaster Risk Management and Climate change adaptation in Bangladesh policy level. Global Journal of Human Social Science 13: 55-65.

Healy, Andrew, and Neil Malhotra. 2009. Myopic voters and natural disaster policy. American Political Science Review 103: 387-406. [CrossRef]

Helmke, Gretchen, and Steven Levitsky. 2004. Informal institutions and comparative politics: A research agenda. Perspectives on Politics 2: 725-40. [CrossRef]

Henseler, Jörg, Christian M. Ringle, and Rudolf R. Sinkovics. 2009. The use of partial least squares path modeling in international marketing. In New Challenges to International Marketing. Bradford: Emerald Group Publishing Limited, pp. $277-319$.

Henseler, Jörg, Geoffrey Hubona, and Pauline Ash Ray. 2017. Partial least squares path modeling: Updated guidelines. In Partial Least Squares Path Modeling. Berlin: Springer, pp. 19-39.

Hewitt, Kenneth. 1995. Excluded perspectives in the social construction of disaster. International Journal of Mass Emergencies and Disasters 13: 317-39.

Hinkin, Timothy R., and Chester A. Schriesheim. 1989. Development and application of new scales to measure the French and Raven (1959) bases of social power. Journal of Applied Psychology 74: 561. [CrossRef]

Homer, Pamela M., and Lynn R. Kahle. 1988. A structural equation test of the value-attitude-behavior hierarchy. Journal of Personality and social Psychology 54: 638. [CrossRef]

Hoque, Rakibul, and Golam Sorwar. 2017. Understanding factors influencing the adoption of mHealth by the elderly: An extension of the UTAUT model. International Journal of Medical Informatics 101: 75-84. [CrossRef]

Hoyle, Rick H. 2012. Handbook of Structural Equation Modeling. New York: Guilford press.

IPCC. 2012. Managing the Risks of Extreme Events and Disasters to Advance Climate Change Adaptation: Special Report of the Intergovernmental Panel on Climate Change. Cambridge: Cambridge University Press.

Islam, M. M. 2014. The Politics of the Public Food Distribution System in Bangladesh: Regime Survival or Promoting Food Security? Journal of Asian and African Studies 50: 702-15. [CrossRef]

Islam, Shafiqul, Cordia Chu, and James C. R. Smart. 2019. A Political Economy Analysis of Public Spending Distribution for Disaster Risk Reduction in Bangladesh. European Journal of Sustainable Development 8: 358-58. [CrossRef]

Islam, Shafiqul, Cordia Chu, Leong Liew, and James C. R. Smart. 2020a. Distributing flood shelters for disaster risk reduction: Exploring the practices in Bangladesh from a political economy perspective. Disaster Prevention and Management: An International Journal 29: 322-39. [CrossRef]

Islam, Shafiqul, Cordia Chu, and James Smart. 2020b. Challenges in integrating disaster risk reduction and climate change adaptation: Exploring the Bangladesh case. International Journal of Disaster Risk Reduction 47: 101540. [CrossRef]

Islam, Shafiqul, Cordia Chu, James C. R. Smart, and Leong Liew. 2020c. Integrating disaster risk reduction and climate change adaptation: A systematic literature review. Climate and Development 12: 255-67. [CrossRef]

Izumi, Takako, and Rajib Shaw. 2014. A New Approach of Disaster Management in Bangladesh: Private Sector Involvement. Risk, Hazards $\mathcal{E}$ Crisis in Public Policy 5: 425-43.

Jha, M. K. 2015. Liquid disaster and frigid response: Disaster and social exclusion. International Social Work 58: 704-16. [CrossRef]

Kahle, Lynn R. 1983. Social Values and Social Change: Adaptation to Life in America. Westport: Praeger Publishers.

Karim, Azreen, and Ilan Noy. 2020. Risk, poverty or politics? The determinants of subnational public spending allocation for adaptive disaster risk reduction in Bangladesh. World Development 129: 104901. [CrossRef]

Keefer, Philip. 2009. Disastrous consequences: The political economy of disaster risk reduction. World Bank Working Paper, Washington: World Bank.

Kelman, Ilan, and Jean Christophe Gaillard. 2010. Embedding climate change adaptation within disaster risk reduction. Climate Change Adaptation and Disaster Risk Reduction: Issues and Challenges 4: 23-46.

Kelman, Ilan, J. C. Gaillard, and Jessica Mercer. 2015. Climate change's role in disaster risk reduction's future: Beyond vulnerability and resilience. International Journal of Disaster Risk Science 6: 21-27. [CrossRef]

Kenny, C. 2012. Disaster risk reduction in developing countries: Costs, benefits and institutions. Disasters 36: 559-88. [CrossRef]

Lee, Julie Anne, Geoffrey N. Soutar, and Jordan Louviere. 2007. Measuring values using best-worst scaling: The LOV example. Psychology \& Marketing 24: 1043-58.

Liu, Qingrong, Chengqing Ruan, Shan Zhong, Jian Li, Zhonghui Yin, and Xihu Lian. 2018. Risk assessment of storm surge disaster based on numerical models and remote sensing. International Journal of Applied Earth Observation and Geoinformation 68: 20-30. [CrossRef]

Mallick, Bishawjit. 2014. Cyclone shelters and their locational suitability: An empirical analysis from coastal Bangladesh. Disasters 38: 654-71. [CrossRef] [PubMed]

Marks, Danny, and Louis Lebel. 2016. Disaster governance and the scalar politics of incomplete decentralization: Fragmented and contested responses to the 2011 floods in Central Thailand. Habitat International 52: 57-66. [CrossRef] 
Marzagão, Daniela Santana Lambert, and Marly M Carvalho. 2016. Critical success factors for Six Sigma projects. International Journal of Project Management 34: 1505-18. [CrossRef]

Mercer, Jessica. 2010. Disaster risk reduction or climate change adaptation: Are we reinventing the wheel? Journal of International Development 22: 247-64. [CrossRef]

Ministry of Disaster Management, and Relief, GOB. 2008. Construction of Flood Shelter in Flood-Prone and River-Erosion Prone Areas. Available online: http://www.ddm.gov.bd/site/view/miscellan-ous_info/\%E0\%A6\%AC\%E0\%A6\%A8\%E0\%A7\%8 D\%E0\%A6\%AF\%E0\%A6\%BE\%20\%E0\%A6\%86\%E0\%A6\%B6\%E0\%A7\%8D\%E0\%A6\%B0\%E0\%A7\%9F\%E0\%A6\%95\%E0\%A7 $\% 87 \% \mathrm{E} 0 \% \mathrm{~A} 6 \% \mathrm{~A} 8 \% \mathrm{E} 0 \% \mathrm{~A} 7 \% 8 \mathrm{D} \% \mathrm{E} 0 \% \mathrm{~A} 6 \% \mathrm{~A} 6 \% \mathrm{E} 0 \% \mathrm{~A} 7 \% 8 \mathrm{D} \% \mathrm{E} 0 \% \mathrm{~A} 6 \% \mathrm{~B} 0 /$ (accessed on $15 \mathrm{June} 2019$ ).

Ministry of Disaster Management, and Relief, GOB. 2010a. National Plan for Disaster Management 2010-2015. Available online: https: / / modmr.gov.bd/ (accessed on 15 July 2018).

Ministry of Disaster Management, and Relief, GOB. 2012. Disaster Management Act 2012. Available online: https://modmr.gov.bd/ site/view /law /\%E0\%A6\%86\%E0\%A6\%87\%E0\%A6\%A8-\%E0\%A6\%93-\%E0\%A6\%AC\%E0\%A6\%BF\%E0\%A6\%A7\%E0\%A6 $\%$ BF (accessed on 15 August 2019).

Ministry of Disaster Management, and Relief, GOB. 2015. National Disaster Management Policy 2015. Available online: https://modmr.gov.bd/site/view/policies/\%E0\%A6\%A8\%E0\%A7\%80\%E0\%A6\%A4\%E0\%A6\%BF\%E0\%A6\%AE\%E0\%A6 $\%$ BE $\%$ E0 \% A6\%B2\%E0\%A6\%BE-\%E0\%A6\%93-\%E0\%A6\%A8\%E0\%A6\%BF\%E0\%A6\%B0\%E0\%A7\%8D \%E0\%A6\%A6\%E0\%A7 $\% 87 \% \mathrm{E} 0 \% \mathrm{~A} 6 \% \mathrm{~B} 6 \% \mathrm{E} 0 \% \mathrm{~A} 6 \% \mathrm{BF} \% \mathrm{E} 0 \% \mathrm{~A} 6 \% 95 \% \mathrm{E} 0 \% \mathrm{~A} 6 \% \mathrm{BE}$ (accessed on 6 March 2019).

Ministry of Environment, and Forest, GOB. 2008. Bangladesh Climate Change Strategy and Action Plan 2008; Dhaka: Ministry of Environment \& Forests, Government of the People's Republic of Bangladesh.

Mirza, M. Monirul Qader. 2002. Global warming and changes in the probability of occurrence of floods in Bangladesh and implications. Global Environmental Change 12: 127-38. [CrossRef]

Mitchell, Tom, Maarten Van Aalst, and Paula Silva Villanueva. 2010. Assessing Progress on Integrating Disaster Risk Reduction and Climate Change Adaptation in Development Processes. Brighton: Institute of Development Studies.

Mogues, Tewodaj. 2015. Political economy determinants of public spending allocations: A review of theories, and implications for agricultural public investment. European Journal of Development Research 27: 452-73. [CrossRef]

Muñoz, Cristina E., and Eric Tate. 2016. Unequal recovery? Federal resource distribution after a Midwest flood disaster. International Journal of Environmental Research and Public Health 13: 507.

Muthupoltotage, Udayangi Perera, and Lesley Gardner. 2018. Analysing the Relationships between Digital Literacy and Self-Regulated Learning of Undergraduates-A Preliminary Investigation. In Advances in Information Systems Development. Berlin: Springer, pp. $1-16$.

Næss, Lars Otto, Guri Bang, Siri Eriksen, and Jonas Vevatne. 2005. Institutional adaptation to climate change: Flood responses at the municipal level in Norway. Global Environmental Change 15: 125-38. [CrossRef]

Neal, Jennifer Watling, and Zachary P. Neal. 2011. Power as a structural phenomenon. American Journal of Community Psychology 48: 157-67. [CrossRef]

Neumayer, Eric, Thomas Plümper, and Fabian Barthel. 2014. The political economy of natural disaster damage. Global Environmental Change 24: 8-19. [CrossRef]

Petrides, K. V., and Adrian Furnham. 2000. On the dimensional structure of emotional intelligence. Personality and Individual Differences 29: 313-20. [CrossRef]

Purdon, Mark. 2015. Advancing Comparative Climate Change Politics: Theory and Method. Global Environmental Politics 15: 1-26. [CrossRef]

Rawlani, Amireeta K., and Benjamin K. Sovacool. 2011. Building responsiveness to climate change through community based adaptation in Bangladesh. Mitigation and Adaptation Strategies for Global Change 16: 845-63. [CrossRef]

Roine, Johanna, Liisa Uusitalo, and Anna Hielm-Björkman. 2016. Validating and reliability testing the descriptive data and three different disease diagnoses of the internet-based DOGRISK questionnaire. BMC Veterinary Research 12: 30. [CrossRef]

Roldán, José L., and Manuel J. Sánchez-Franco. 2012. Variance-based structural equation modeling: Guidelines for using partial least squares. In Research Methodologies, Innovations and Philosophies in Software Systems Engineering and Information Systems. Philadelphia: IGI Global, p. 193.

Rose, Adam, and Tyler Kustra. 2013. Economic Considerations in Designing Emergency Management Institutions and Policies for Transboundary Disasters. Public Management Review 15: 446-62. [CrossRef]

Sabur, AKM Abdus. 2012. Disaster Management system in Bangladesh: An overview. India Quarterly 68: 29-47. [CrossRef]

Saunders, Mark, Philip Lewis, Adrian Thornhill, and Jonathan Wilson. 2009. Business Research Methods. Financial Times. London: Prentice Hall.

Sawada, Yasuyuki, and Yoshito Takasaki. 2017. Natural disaster, poverty, and development: An introduction. World Development 94: 2-15. [CrossRef]

Schipper. 2009. Meeting at the crossroads?: Exploring the linkages between climate change adaptation and disaster risk reduction. Climate and Development 1: 16-30. [CrossRef]

Seabright, Paul. 1993. Managing local commons: Theoretical issues in incentive design. Journal of Economic Perspectives 7: 113-34. [CrossRef]

Serrat, Olivier. 2017. Political economy analysis for development effectiveness. In Knowledge Solutions. Berlin: Springer, pp. 207-22. 
Shaw, Rajib, Fuad Mallick, and Aminul Islam. 2013. Disaster Risk Reduction Approaches in Bangladesh. Berlin: Springer.

Smith, Adam. 1937. The Wealth of Nations. New York: Modern Library, First publish 1776.

Sokefeld, Martin. 2011. Exploring the Link between Natural Disasters and Politics: The Case Studies of Pakistan and Peru? Scrutiny 5: 1 .

Sovacool, Benjamin K. 2018. Bamboo beating bandits: Conflict, inequality, and vulnerability in the political ecology of climate change adaptation in Bangladesh. World Development 102: 183-94. [CrossRef]

Sovacool, Benjamin, and Björn-Ola Linnér. 2015. The Political Economy of Climate Change Adaptation. Berlin: Springer.

Sovacool, Benjamin K., Björn-Ola Linnér, and Michael E. Goodsite. 2015. The political economy of climate adaptation. Nature Climate Change 5: 616-18. [CrossRef]

Sovacool, Benjamin K., Björn-Ola Linnér, and Richard J. T. Klein. 2016. Climate change adaptation and the Least Developed Countries Fund (LDCF): Qualitative insights from policy implementation in the Asia-Pacific. Climatic Change 140: 1-18. [CrossRef]

Sovacool, Benjamin K., May Tan-Mullins, and Wokje Abrahamse. 2018. Bloated bodies and broken bricks: Power, ecology, and inequality in the political economy of natural disaster recovery. World Development 110: 243-55. [CrossRef]

Stiglitz, Joseph. 1998. Distinguished Lecture on Economics in Government: The Private Uses of Public Interests: Incentives and Institutions. The Journal of Economic Perspectives 12: 3-22. [CrossRef]

Tashmin, Nushrat. 2016. Can climate finance in Bangladesh be helpful in making transformational change in ecosystem management? Environmental Systems Research 5: 2. [CrossRef]

Thomalla, Frank, Rasmus Klocker Larsen, Fareedali Kanji, and Sopon Naruchaikusol. 2009. From Knowledge to Action: Learning to Go the Last Mile: A Participatory Assessment of the Conditions for Strengthening the Technology-Community Linkages of Tsunami Early Warning Systems in the Indian Ocean. Stockholm: Stockholm Environment Institute.

Transparency International Bangladesh. 2017. Climate Finance and Local Government Institutions: Governance in Project Implementation. Available online: https:/ / www.ti-bangladesh.org/beta3/index.php/en/highlights/5140-climate-finance-and-localgovernment-institutions-governance-in-project-implementation-english (accessed on 12 December 2019).

UNISDR. 2005. Hyogo Framework for Action 2005-2015. Available online: https:/ /www.unisdr.org/we/coordinate/hfa (accessed on 19 November 2019).

UNISDR. 2015. The State of DRR at the Local Level: A 2015 Report on the Patterns of Disaster Risk Reduction Actions at Local Level. Available online: http://www.unisdr.org/we/inform/publications (accessed on 30 October).

Venton, Paul, and Sarah La Trobe. 2008. Linking Climate Change Adaptation and Disaster Risk Reduction. Teddington: Institute of Development Studies, p. 16.

Vilares, Manuel J., Maria H. Almeida, and Pedro S. Coelho. 2010. Comparison of likelihood and PLS estimators for structural equation modeling: A simulation with customer satisfaction data. In Handbook of Partial Least Squares. Berlin/Heidelberg: Springer, pp. 289-305.

Vishwanath, Arun, and Susan D. Scamurra. 2007. Barriers to the adoption of electronic health records: Using concept mapping to develop a comprehensive empirical model. Health Informatics Journal 13: 119-34. [CrossRef]

Vorhies, Francis. 2012. The Economics of Investing in Disaster Risk Reduction. Geneva: UN International Strategy for Disaster Reduction.

Wade, Robert. 1986. Common property resource management in South Indian villages. Common Property Resource Management. Available online: https:/ / www.semanticscholar.org/paper/Common-property-resource-management-in-South-Indian-Wade/ 9a750a36c57785b252d3a04d1f134f36c2e70f00 (accessed on 23 June 2019).

Watts, Michael. 2000. Political ecology. A companion to Economic Geography 257: 274.

Wisner, B., Piers Blaikie, Terry Cannon, and Ian Davis. 2003. At Risk: Natural Hazards, People's Vulnerability and Disasters, 2nd ed. New York: Routledge.

Xie, Wei, Adam Rose, Shantong Li, Jianwu He, Ning Li, and Tariq Ali. 2018. Dynamic economic resilience and economic recovery from disasters: A quantitative assessment. Risk Analysis 38: 1306-18. [CrossRef] [PubMed]

Ye, Yunming, Qingyao Wu, Joshua Zhexue Huang, Michael K. Ng, and Xutao Li. 2013. Stratified sampling for feature subspace selection in random forests for high dimensional data. Pattern Recognition 46: 769-87. [CrossRef]

Zobair, Khondker Mohammad, Louis Sanzogni, and Kuldeep Sandhu. 2019. Expectations of telemedicine health service adoption in rural Bangladesh. Social Science \& Medicine 238: 112485. 